\title{
Isotopic tracing of clear water sources in an urban sewer: A combined water and dissolved sulfate stable isotope approach
}

\author{
J. HOUHOU ${ }^{1 *}$, B.S. LARTIGES ${ }^{1 *}$, C. FRANCE-LANORD ${ }^{2}$,

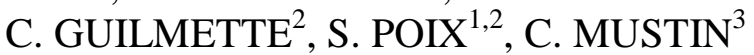 \\ ${ }^{1}$ Nancy University - LEM-ENSG/INPL-CNRS, Pôle de l'Eau, 15 Avenue du Charmois, BP 40 \\ 54501 Vandouvre Cedex, France \\ ${ }^{2}$ Nancy University - CRPG-CNRS, 15 rue notre dame des pauvres, BP20, 54501 \\ Vandoeuvre Cedex, France \\ ${ }^{3}$ Nancy University - LIMOS - BP 70239 - 54506 Vandoeuvre Cedex, France
}

(*) To whom correspondence should be addressed

E-mail: bruno.lartiges@get.omp.eu

jamil.houhou@hotmail.fr 


\begin{abstract}
This paper investigates the potential of stable isotopes of both water ( $\delta \mathrm{D}$ and $\delta^{18} \mathrm{O}_{\mathrm{H} 2 \mathrm{O}}$ ) and dissolved sulfate $\left(\delta^{34} \mathrm{~S}\right.$ and $\left.\delta^{18} \mathrm{O}_{\mathrm{SO} 4}\right)$ for determining the origin and the amount of clear waters entering an urban sewer. The dynamics of various hydrological processes that commonly occur within the sewer system such as groundwater infiltration, rainwater percolation, or stormwater release from retention basins, can be readily described using water isotope ratios. In particular, stable water isotopes indicate that the relative volumes of infiltrated groundwater and sewage remain approximately constant and independent of wastewater flow-rate during the day, thus demonstrating that the usual quantification of parasitic discharge from minimal nocturnal flow measurements can lead to completely erroneous results. The isotopic signature of dissolved sulfate can also provide valuable information about the nature of water inputs to the sewage flow, but could not be used in our case to quantify the infiltrating water. Indeed, even though the microbial activity had a limited effect on the isotopic composition of dissolved sulfate at the sampling sites investigated, the dissolved sulfate concentration in sewage was regulated by the formation of barite and calcium-phosphate mineral species. Sulfate originating from urine was also detected as a source using the oxygen isotopic composition of sulfate, which suggests that $\delta^{18} \mathrm{O}_{\mathrm{SO} 4}$ might find use as a urine tracer.
\end{abstract}




\section{INTRODUCTION}

The reduction of groundwater infiltration and stormwater inflow in sewer systems is a major concern in urban water management (Marsalek et al. 2006). On a general basis, groundwater infiltration occurs through cracks or loose joints in sewer pipes, whereas in separate sewers, inflow is the result of improper connections between storm and sanitary sewers. Estimates of clear water discharge reported in the literature range from 30 to $72 \%$ of the sewage flow (Valiron and Tabuchi 1992; Verbanck 1993; Kracht and Gujer 2005; Kracht et al. 2007). Therefore, the extraneous flow drastically increases the costs associated with sewage treatment, the problem being magnified in wet weather especially as sudden inflows of clear rainwater often cause severe dysfunctioning of the treatment plant.

The total amount of clear water entering the sewer system is classically inferred from the minimal nocturnal flow of wastewater (Chocat 1997). Such an approach is rarely reliable, and further methods have been proposed to assess more accurately the volume of extraneous flow. Thus, the fraction of clear water has been obtained by following both the wastewater flow and the concentration of specific sewage components such as borates (Verbanck 1993), or chemical oxygen demand (Kracht and Gujer 2005). In recent years, water isotope tracers (D and ${ }^{18} \mathrm{O}$ ) have become increasingly used in the context of the urban hydrological cycle, essentially to investigate the groundwater recharge from leaky sewers and water mains (Butler and Verhagen 1997; Barrett et al. 1999; Navarro et al. 2007). Thus, Kracht et al. (2007) demonstrated that stable isotopes of water show promise for monitoring both the origin and the amount of extraneous waters in the sewer system. This method only requires that the isotopic signature of sewage be distinct from that of infiltrating water, which is the case in most cities where drinking water - a proxy for sewage - is imported from outside the urban catchment area.

However, the hydrological processes that occur in a sewer system can be quite complex, and the extraneous flow may involve more than two water sources. A multi-isotopic approach and/or supplementary hydrochemistry data are then required to quantify the various components of clear water (Barrett et al. 1999). Stable isotopes in dissolved sulfate $\left({ }^{34} \mathrm{~S}\right.$ and ${ }^{18} \mathrm{O}_{\mathrm{SO} 4}$ ) have been considered for tracing water sources in urban aquifers (Barrett et al. 1999; Osenbrück et al. 2007). Indeed, the wide range of sulfate isotopic signatures make those isotopes particularly sensitive indicators for investigating hydrological processes, provided that microbially mediated sulfate reduction does not alter the isotopic content of dissolved 
sulfate (Knöller et al. 2008). The purpose of this study was then to explore the potential of stable isotopes of both water and dissolved sulfate, as tools to identify and to quantify the various sources that enter the sewer system in Greater Nancy urban community.

\section{EXPERIMENTAL SECTION}

Study area. This study was conducted in the Greater Nancy urban catchment between Novembre 2004 and December 2006. Nancy, a city of about 270,000 inhabitants located in north-eastern France, lies on both banks of the Meurthe river with a total catchment area of $193 \mathrm{Km}^{2}$ (144 km² on left bank) (fig. 1). As the Meurthe river water is brackish, the municipal water system is supplied with treated surface water originating from the Moselle river. The source of the Moselle river is located in the Vosges mountains, $250 \mathrm{~km}$ southeast of Nancy. The Moselle river mainly drains silicate formations in the upper part of the catchment, whereas it flows on carbonate and evaporite sediments downstream of Epinal (Brenot et al. 2007). The imported water is pumped at Messein and conveyed to the drinking water treatment plant through two $11 \mathrm{~km}$ aqueducts. Three reservoirs with a total storage capacity of $2.510^{6} \mathrm{~m}^{3}$ secures the water supply in case of pollution or high turbidity level in the Moselle river. The drinking water distribution system delivers daily about $67600 \mathrm{~m}^{3}$ via $950 \mathrm{~km}$ of pipes and 33 storage facilities (Total capacity of $600000 \mathrm{~m}^{3}$ ). Approximately $26 \%$ of drinking water is lost through leakage.

The sewer system comprises about $1200 \mathrm{~km}$ of pipes, $250 \mathrm{~km}$ of them man-entry sewer (pipe diameter $\geq 1.2 \mathrm{~m}$ ). As Nancy is established in basin position surrounded by hills dominating the Meurthe valley by about $200 \mathrm{~m}$, the slope of the gravity sewer pipe may reach $5 \%$. The central core of Nancy urban community is served by a combined sewer, whereas the peripheral areas are drained by separate systems. 25 detention basins $\left(180000 \mathrm{~m}^{3}\right.$ storage capacity) have been constructed to limit discharges from combined sewer overflows in the Meurthe river.

As depicted in figure 1, the geological subsurface of Nancy area is composed of three main units: the downtown area is underlain by Meurthe river alluvial deposits, Toarcian shales extend to the hillsides, whereas Bajocian recifal limestone caps the surrounding hills. Shallow aquifers are found in the three geological units, their hydraulic head being monitored from 40 piezometers spread over the catchment area. However, the rather narrow diameter of most piezometers prevented groundwater sampling with the submersible pump in the vicinity 
of sewage sampling sites. Groundwater recharge occurs mainly from rainfall infiltration, leakage from water mains being negligible $(<4 \%$ over the catchment area).

The local climate is continental with an average annual precipitation of $760 \mathrm{~mm}$ occuring mostly during summer. Temperature and precipitation data were obtained from Nancy-Essey meteorological weather station, whereas Moselle river flow discharge data were measured at nearby gauge Tonnoy (Hydro Bank, Moselle Tonnoy Station, A5110610).

Sample collection and analysis. Three sampling campaigns (29-30 March 2005, 4-5 April 2006, 25-26 October 2006) are reported in this paper. The location of sampling sites for sewage, drinking water, rainwater, and groundwater is shown in figure 1. A detailed description of those sampling sites has been provided in a previous publication (Houhou et al. 2009). Supplementary information on piezometers location and characteristics are given in table 1. Figure 2 shows the temporal evolution of rainfall amounts and Moselle river flow discharge during the month preceding each of three sampling campaigns. Sampling was generally conducted in dry weather, the minor precipitation event on March 29 not generating surface runoff. It should be noted that snowfalls occurred during the last two weeks of February 2005, which then led to the application of deicing salts on the roads.

Grab-samples of sewage were taken from the sewer through open manholes using a polyethylene bucket, whereas groundwater was collected from piezometers using a portable submersible pump (Mini-Twister (9.5 L/min) SDEC France). The piezometer was first purged for at least three well volumes before being sampled. Integrated rainwater samples were collected between September 2006 and November 2006 using a homemade sampler placed on the roof of LEM laboratory. Tap water was sampled at CRPG and LEM laboratories before and after the sewage sampling campaigns. Prior to sampling, the faucet was left open for 15 minutes.

Sample characteristics such as temperature, $\mathrm{pH}$, conductivity, dissolved oxygen concentration, redox potential (WTW, Multiline F/SET) were measured immediately after collection. The water sample was then filtered on-site through pre-washed $0.22 \mu \mathrm{m}$ pore-size cellulose-acetate membranes (Chromafil CA-20/25) and split into five aliquots for cations, anions, dissolved organic carbon (DOC), and isotopic analyses. The filtrates were stored in 65 $\mathrm{mL}$ polyethylene or glass bottles at $4^{\circ} \mathrm{C}$ until analysis. Soluble cation and trace element concentrations were measured on $\mathrm{HNO}_{3}$ acidified samples using a Jobin-Yvon JY70 ICPAES (Inductively Coupled Plasma Atomic Emission Spectrometry) and Perkin-Elmer ELAN 6000 ICP-MS (Inductively Coupled Plasma Mass Spectrometry), respectively. Uncertainties 
were better than $2 \%$ for major cations and $5 \%$ for trace elements. Sulfate, chloride, nitrate, and phosphate anions were determined by ion chromatography using a Dionex ICS-3000 (AS9-HC column). The lower dectection limits were $50 \mathrm{ppb}$ for $\mathrm{PO}_{4}$ and $20 \mathrm{ppb}$ for the other anions. DOC was measured with a Dohrman 190 analyzer.

The oxygen isotope composition of water was measured by the conventional $\mathrm{H}_{2} \mathrm{O}-\mathrm{CO}_{2}$ equilibration method (Epstein and Mayeda 1953), using a modified VG 602D dual-inlet mass spectrometer. $\mathrm{D} / \mathrm{H}$ isotopic ratio was obtained with a Isoprime mass spectrometer (GV Istruments, Manchester, UK) coupled with an elemental analyzer EA3000 after reducing the water to hydrogen gas on chromium at $1050^{\circ} \mathrm{C}$ (Morrison et al. 2001). The dissolved sulfate in water samples and the aluminum coagulant used at the drinking water plant, were precipitated as $\mathrm{BaSO}_{4}$ by adding a $5 \% \mathrm{BaCl}_{2}$ solution (Brenot et al. 2007; Calmels et al. 2007). In order to prevent $\mathrm{BaCO}_{3}$ co-precipitation, the water samples were first acidified with $\mathrm{HCl}$ to $\mathrm{pH} 4.2$ and then heated to boiling point to ensure a complete removal of $\mathrm{CO}_{2} \cdot \mathrm{BaSO}_{4}$ precipitates were carefully washed and dried, and purity was checked by X-ray Diffraction (Bruker D8 diffractometer). The sulphur isotopic composition was analyzed from the $\mathrm{SO}_{2}$ released from $\mathrm{BaSO}_{4}$ at $1100^{\circ} \mathrm{C}$ in presence of $\mathrm{Sn}$ and tungsten oxide (Giesemann et al. 1994), whereas the ${ }^{18} \mathrm{O} /{ }^{16} \mathrm{O}$ of $\mathrm{SO}_{4}$ was determined from the $\mathrm{CO}$ generated by mixtures of $\mathrm{BaSO}_{4}$ and glassy carbon at $1270^{\circ} \mathrm{C}$ in presence of $\mathrm{Ni}$ catalyst (Koziet 1997). ${ }^{34} \mathrm{~S} /{ }^{32} \mathrm{~S}$ and ${ }^{18} \mathrm{O} /{ }^{16} \mathrm{O}$ isotopic ratios of sulfate were measured using a $\mathrm{GV}$ Instruments Isoprime mass spectrometer coupled in continuous flow mode with a EuroVector elemental analyzer.

The results are reported in $\delta$-notation $\left(\delta^{18} \mathrm{O}_{\mathrm{H} 2 \mathrm{O}}, \delta \mathrm{D}, \delta^{34} \mathrm{~S}, \delta^{18} \mathrm{O}_{\mathrm{SO} 4}\right)$, i.e. the permil deviation of the measured isotopic ratio $\left(\mathrm{R}_{\text {sample }}\right)$ relative to a reference material $\left(\mathrm{R}_{\text {ref.mat. }}\right)$ :

$$
=\left(\begin{array}{ll}
\frac{R_{\text {sample }}}{R_{\text {ref.mat. }}} & 1
\end{array}\right) * 1000
$$

The standards materials are V-SMOW (Vienna Standard Mean Ocean Water) for $\delta^{18} \mathrm{O}_{\mathrm{H} 2 \mathrm{O}}$, $\delta^{18} \mathrm{O}_{\mathrm{SO} 4}$ and $\delta \mathrm{D}$, and CDT (Canyon Diablo Troilite) for $\delta^{34} \mathrm{~S}$. The accuracy of isotopic analyses was estimated by replicate analyses of internal-standards along with the sample series. Data presented in this study are given with uncertainty of $\pm 0.2 \%$ and $\pm 1 \%$ for $\delta^{18} \mathrm{O}_{\mathrm{H} 2 \mathrm{O}}$ and $\delta \mathrm{D}$ respectively, and the overall reproducibility $(2 \sigma$ level $)$ of $\delta^{18} \mathrm{O}_{\mathrm{SO} 4}$ and $\delta^{34} \mathrm{~S}$ analyses is better than $0.3 \%$ using the barium sulfate NBS 127 international reference. 


\section{RESULTS AND DISCUSSION}

Suitability of isotopic systems. The identification of various water sources that may contribute to the flow of sewage requires, to the least, measurable isotopic differences between them. Previous successful studies using stable isotopes of water in an urban context relied on quasiconstant hydrological differences between the source of water supply (i.e. reservoir or lake water) and the local groundwater (Butler and Verhagen 1997; Kracht et al. 2007). In our case, the water supply comes from treated Moselle river water, which implies that drinking water, and hence domestic sewage, possess a distinct isotope composition from local rainwater and groundwater. Indeed, the isotopic signature of meteoric waters depends on local geographic and climatic factors, whereas that of groundwater integrates over time the composition of water inputs (precipitation, mains and sewer leaks...) that recharge the aquifer (Mook 2001). However, the hydrological regime of a river may strongly influence the isotopic signal of the surface water (Mook 2001), and accordingly that of the corresponding treated water. As illustrated in figure 3 , the temporal evolution of $\delta \mathrm{D}$ values from tap water collected at CRPG over a four month period, clearly follows the discharge of the Moselle river with a temporal shift of about 4 days. A decrease in $\delta \mathrm{D}$ that ranges from 2 to $5 \%$, can be measured after each peak in flow discharge. The temporal shift between the two curves includes both the transport of surface water from the pumping facility to the treatement plant, the treatment of raw water, and the residence time within the drinking water distribution system. As a result, a drinking water of slightly varying isotopic composition may be supplied over the urban community. Nevertheless, the deviation in $\delta \mathrm{D}$ was not observed to exceed $2 \%$ over two consecutive days, which is the magnitude of analytical uncertainty for $\delta \mathrm{D}$.

The applicability of stable sulfate isotopes to differentiate water inputs in the sewer system is more arguable. On the one hand, dissolved sulfate may be derived from a variety of sources (evaporite dissolution, sulfide minerals oxidation, atmospheric precipitation,...), whose distinct isotopic signatures make $\delta^{34} \mathrm{~S}$ and $\delta^{18} \mathrm{O}_{\mathrm{H} 2 \mathrm{O}}$ effective indicators for investigating hydrological processes (Berner et al. 2002; Osenbrück et al. 2007). On the other hand, dissolved sulfate rarely behaves as a conservative tracer, both its concentration and its isotopic composition being most often affected by a combination of redox reactions and physico-chemical processes such as $\mathrm{H}_{2} \mathrm{~S}$ release and mineral sulfide precipitation (van Everdingen and Krouse 1985; Knöller et al. 2008). In the sewer system, microbially mediated sulfate reduction is likely to occur (Zhang et al. 2008). This would induce significant, but not easily predictible, isotopic fractionations essentially characterized by an enrichment in heavier 
isotopes in the remaining dissolved sulfate (Chambers and Trudinger 1979; Rudnicki et al. 2001 and references herein). Such fractionation could then drastically alter the initial isotopic composition of sulfate.

In the present study, the isotopic signatures of local water sources should allow a ready discrimination: the $\delta^{34} \mathrm{~S}$ values of dissolved sulfate in Moselle river water vary from $12.1 \%$ to $13.4 \%$ with little seasonal variation (Brenot et al. 2007), that of rainwater are about 5.8\% (Brenot et al. 2007) which is consistent with the range of published values for atmospheric sulfate derived from anthropogenic sources ( $\mathrm{Yu}$ et al. 2007), whereas groundwater from Toarcian aquifers should display a negative isotopic signal as dissolved sulfate originates in that case from sulfide oxidation (Goldhaber and Kaplan 1980). Such isotopic contents should not be significantly modified during sewage transport as the sloped catchment maintains a relatively high oxygen content in most sewer pipes (4.06 $\pm 3.29 \mathrm{mg} / \mathrm{L})$, and thus restricts the activity of sulfate-reducing bacteria (SRB) to biofilms (Vollertsen et al. 2008 and references herein). Moreover, the amount of SRB in sewage was found to be rather limited at our sampling sites (counts lower than 4033 per $\mathrm{mL}$ ) (see the supporting information material).

Stability of water and sulfate isotopic signatures in the sewer. Figure $4 a$ shows the $\delta \mathrm{D}-$ $\delta^{18} \mathrm{O}_{\mathrm{H} 2 \mathrm{O}}$ plot of sewage samples collected during a diurnal investigation (29 March 2005) from a trunk in the separate domestic sewer that was unlikely to undergo groundwater infiltration. In that context, the temporal evolution of isotope signals is expected to be limited. Indeed, for stable isotopes of water, most of $\delta^{18} \mathrm{O}_{\mathrm{H} 2 \mathrm{O}}-\delta \mathrm{D}$ values fall into a small range that is close to the local meteoric water line (LMWL). However, four samples (sewage taken at 15h50, 02h05, 03h50, and 06h20) clearly diverge to the right of LMWL and show a fair correlation between $\delta \mathrm{D}$ and $\delta^{18} \mathrm{O}_{\mathrm{H} 2 \mathrm{O}}$ values. Such linear trend is reminiscent of a local evaporation line, the observed slope of about 4 being typical of waters undergoing secondary evaporative isotopic enrichment (Gibson et al. 2008). However, a significant increase in sewage flow rate was noted at these particular sampling times. This suggests that the observed correlation would rather correspond to a binary mixing line between two water sources. Groundwaters collected from two piezometers located nearby the study site present a distinct isotopic composition (fig. 4a) and do not identify the unknown end-member source.

The distribution of stable sulfate isotopes $\left(\delta^{18} \mathrm{O}_{\mathrm{SO} 4}\right.$ and $\left.\delta^{34} \mathrm{~S}\right)$ reveals a slightly different pattern (fig. 4b). If the four previous samples are again characterized by a distinct 
trajectory denoted SWML hereafter (StormWater Mixing Line), the other $\delta^{18} \mathrm{O}_{\mathrm{SO} 4}$ values vary from $7.4 \%$ to $11.2 \%$ with an almost constant $\delta^{34} \mathrm{~S}$ at about $6.3 \%$. Interestingly, the isotopic signature of gypsum from evaporite layers $\left(\delta^{34} \mathrm{~S}=14.1 \%\right.$ and $\delta^{18} \mathrm{O}_{\mathrm{SO} 4}=12.6 \%$ ) (Brenot et al. 2007), is situated on SWML, suggesting that this sulfate source contributes to the isotopic composition of four samples. The unknown end-member water source could then correspond to surface runoff, since some gypsum is present in the deicing salt used for melting snow and ice on roadways (Legret and Pagotto 1999). Moreover, as shown in table 2, the concentrations in anions and trace elements of samples collected at $3 \mathrm{~h} 50$ and $06 \mathrm{~h} 20$ are remarkably close to the median compositions of filtered runoff waters collected by Legret and Pagotto (1999). Indeed, the Greater Nancy Hydraulic Department later confirmed that a retention basin collecting stormwater runoff, was emptied in that section of separate domestic sewer during low-flow periods. Assuming that the $6 \mathrm{~h} 20$ sample represents the end-member source, the deviation from LMWL observed for water isotopes suggests that the amount of rainwater evaporated during surface runoff was about $6 \%$ for that particular rain event (Craig and Gordon 1965).

Figure $4 \mathrm{~b}$ also reveals that the isotopic composition of sulphur in drinking water $\left(\delta^{34} \mathrm{~S}\right.$ $=6.70 \%$ ) has undergone a significant depletion in ${ }^{34} \mathrm{~S}$ compared with that of Moselle river water (from $12.1 \%$ to $13.4 \%$ ). Such variation is primarily due to the addition of aluminum sulfate $\left(\delta^{34} S \sim 0 \%\right)$ during the coagulation stage of raw water treatment. Furthermore, as indicated by the arrow in fig. $4 \mathrm{~b}$, the measured $\delta^{18} \mathrm{O}_{\mathrm{SO} 4}$ is generally slightly shifted to the left of possible mixing lines between the aluminum coagulant and the Moselle river water endmember sources. This presumably originates from the oxidation of carbon-bonded sulphur contained in natural organic matter (Brenot et al. 2007), the raw water being chlorinated at the pumping facility and the clarified water undergoing ozonation at the treatment plant. The $\delta^{34} \mathrm{~S}$ value of carbon-bonded sulphur is generally similar to that of initial sulfate contained in rainwater, i.e. about $5.8 \%$ in the present study (Brenot et al. 2007), and it does not significantly change upon re-oxidation (Krouse and Grinenko 1991).

The isotopic signal of sulphur remains relatively constant in sewage samples during the diurnal investigation, whereas that of oxygen presents a slight enrichment in lighter ${ }^{16} \mathrm{O}$ for most of them (fig. 4b). Such variation in oxygen isotopic composition suggests that a supplementary source contributes to the dissolved sulfate pool in sewage. The fair correlation obtained between $\delta^{18} \mathrm{O}_{\mathrm{SO} 4}$ and phosphate concentration (fig. 5a) identifies sulfate from human excreta as a potential source. Indeed, inorganic sulfate represents the main end-product of 
sulfur metabolism in the human body, though other forms such as ester sulfate represent a 9$15 \%$ fraction of urinary sulfate (Hoffer et al. 2005). Sulfate excreted in urine derives from the oxidation of aminoacids such as cysteine and methionine. To our knowledge, the $\delta^{18} \mathrm{O}_{\mathrm{SO} 4}$ value generated by such a process has not been documented in the literature. Our own measurements obtained from the urine of three healthy people drinking only Greater Nancy tap water, gave values around $4.5 \%$ for $\delta^{34} \mathrm{~S}$ and between $5.9 \%$ to $7.5 \%$ for $\delta^{18} \mathrm{O}_{\mathrm{SO} 4}$ (fig. $4 b$ ). It should be noted that sulfate esters are not precipitated upon $\mathrm{BaCl}_{2}$ addition (Lundquist et al. 1980), and that the oxygen isotopic composition of such compounds is not taken account in the $\delta^{18} \mathrm{O}_{\mathrm{SO} 4}$ of urinary sulfate. The fate of sulfate esters in the sewer has not been described in the literature, but they are likely to generate inorganic sulfate upon microbial hydrolysis (Fitzgerald 1976).

In principle, the relative contribution of dissolved sulfate from urine in sewage can be calculated from:

$$
{ }^{18} \mathrm{O}_{\mathrm{SO} 4 \text { (sewage) }}\left[\mathrm{SO}_{4}\right]_{\text {sewage }}=x_{\mathrm{DW}}{ }^{18} \mathrm{O}_{\mathrm{SO} 4(\mathrm{DW})}\left[\mathrm{SO}_{4}\right]_{D W}+x_{\text {urine }}{ }^{18} \mathrm{O}_{\mathrm{SO} 4 \text { (urine) }}\left[\mathrm{SO}_{4}\right]_{\text {urine }}
$$

where $\mathrm{x}_{\mathrm{DW}}$ and $\mathrm{x}_{\text {urine }}$ represent the percentages of drinking water and of urine contained in sewage, respectively. Average [ $\left.\mathrm{SO}_{4}\right]_{\text {urine }}$ is taken equal to $0.016 \mathrm{~mol} / \mathrm{L}$ (Udert et al. 2003). However, negative values of $\mathrm{x}_{\text {urine }}$ are then obtained from equation (1), thus implying a nonconservative behavior for dissolved sulfate. Solubility calculations reveal that the domestic sewage at JB is slightly supersaturated with regard to barite $\left(\mathrm{BaSO}_{4}\right)$ - saturation indices ranging from 0.04 to 0.38 - except during the stormwater discharge episodes from the retention basin (Saturation as low as -2.2). Moreover, Houhou et al (2009) have shown that brushite, a common calcium-phosphate mineral species that controls the dissolved phosphate concentration in Greater Nancy sewage, also incorporates small amounts of sulfate in its lattice. It is then likely that the activity of dissolved sulfate in sewage is regulated by the formation of barium sulfate and phosphate minerals (fig. 5b). Therefore, even though urinary sulfate certainly contributes to the shift in $\delta^{18} \mathrm{O}_{\mathrm{SO}}$, its relative proportion in sewage can not simply be inferred from the oxygen isotopic compositon of dissolved sulfate. It should also be pointed out that the involvement of inorganic sulfate from personal care products and detergents in the $\delta^{18} \mathrm{O}_{\mathrm{SO} 4}$ of sewage is not known either. The highest $\delta^{18} \mathrm{O}_{\mathrm{SO} 4}$ values at $10.6 \%$ and $11.2 \%$ are observed during and just after the afternoon low flow period. No consistent explanation for those two values has yet been identified. 
Tracing parasitic sewer infiltration. Figure 6 a shows the $\delta^{18} \mathrm{O}_{\mathrm{H} 2 \mathrm{O}}-\delta \mathrm{D}$ values of (i) sewage grab-samples collected over a 24 hour sampling period at PVP, (ii) water samples taken the same day from the Gremillon urban stream which is adjacent to the sewer pipe, (iii) groundwater sampled at a nearby piezometer located at about $3 \mathrm{~km}$ downstream of the sampling site, and (iv) drinking water. The isotopic compositions of groundwater and drinking water differ by about 10 times the standard deviation of measurement, which ensures the detection of about $10 \%$ of infiltrated groundwater in sewage. Two outliers (sewage samples collected at $21 \mathrm{~h} 00$ and $24 \mathrm{~h} 00$ ) are shown in fig. 6a but excluded from the discussion.

Three main fields can be distinguished on the graph. Sewage samples taken during day-time are clustered around $\delta^{18} \mathrm{O}_{\mathrm{H} 2 \mathrm{O}}=-8 \%$ o $\delta \mathrm{D}=-54.5 \%$, whereas Gremillon water samples occupy a field around $\delta^{18} \mathrm{O}_{\mathrm{H} 2 \mathrm{O}}=-7.7 \%$ o $\mid \delta \mathrm{D}=-52.8 \%$. Both groups are located near a mixing line between drinking water and groundwater. Assuming binary mixing - e.g. $D_{\text {sewage }}=x_{D W} D_{D W}+x_{G W} D_{G W}(2)$ where $\mathrm{x}_{\mathrm{GW}}$ is the percentage of groundwater in sewage and $\mathrm{x}_{\mathrm{DW}}+\mathrm{x}_{\mathrm{GW}}=1-$ about $63 \%$ of wastewater is composed of infiltrated groundwater, whereas the urban stream should contain approximately $20 \%$ of mains water. Such values are consistent with those calculated from soluble $\mathrm{Ca}$ and $\mathrm{Ni}$ concentrations in groundwater and in drinking water (fig. 7a-b). Gremillon stream may receive sewage, i.e. drinking water, from leaks of the adjacent separate sanitary sewer. However, as several storm drains empty into the urban stream, it may also be contaminated through unintended cross-connections between sanitary sewer and storm sewer pipes. Interestingly, sewage samples collected during nighttime and at $14 \mathrm{~h} 15$ are characterized by $\delta \mathrm{D}$ values sligthly lighter than those of day-time sewage. This indicates that a third end-member source contributes to the flow of sewage in this area. As these water isotope data plot close to the local meteoric water line, they might identify recently infiltrated rainwater.

The $\delta^{34} \mathrm{~S}-\delta^{18} \mathrm{O}_{\mathrm{SO} 4}$ diagram shows that samples from Gremillon stream, day-time and night-time sewage, occupy three fields that clearly overlap (fig. 6b). The relatively low $\delta^{34} \mathrm{~S}$ value at $-10.50 \%$ for sulfate in groundwater may be attributed to the oxidation of sulfide minerals contained in the Toarcian shales that form the shallow aquifer at PVP sampling site (Berner et al. 2002; Calmels et al. 2007). The isotopic composition of sulfates contained in sewage and in the urban stream, is intermediate between those of drinking water and of groundwater. However, the parasitic discharge in the sanitary sewer can not be calculated from isotopic values because the content in dissolved sulfate found in sewage largely exceeds 
that measured in RG groundwater. Such discrepancy likely results from an incorrect identification of an end-member source, i.e. RG groundwater.

Surprisingly, all day-time isotopic values are in the same close range. This implies that the relative volumes of sewage and groundwater remain almost constant in those samples, even though the amount of discharged wastewater obviously varies during the day. In their study of Rümlang sewer system, Kracht et al. (2007) observed the same phenomenon and attributed the diurnal variation of the infiltration discharge to the presence of water pools and backwater zones in the sewer system. A similar explanation can certainly be invoked here. Furthermore, it is puzzling that the large amount of infiltrated groundwater becomes much lesser at night, the additional extraneous flow evidenced at that time being clearly minor during day-time. The presence of a nearby inverted siphon used to convey the sewage underneath a roadway, might explain such phenomenon: a decreased head at the upstream end of the siphon would stop its functioning during low-flow periods, and more particularly at night, the groundwater then infiltrating originating from a different sewer section located downstream of the siphon. These two observations clearly demonstrate that the quantification of clear water discharge from minimal nocturnal flow measurements can lead to erroneous results.

Isotopic tracing in the sewer system at the city scale. Fig. 8a shows the water isotopic compositions of samples collected during the October 2006 campaign in the Greater Nancy catchment area. Drinking water and the majority of sewage samples plot close to the LMWL, whereas most groundwater define a straight line parallel but slightly offset to the right of LMWL. Unfortunately, the isotopic content of drinking water varied significantly during this sampling campaign, which may account for part of the scattering in sewage samples. Nevertheless, it is clear that most sewage samples are influenced by rainwater, their position being roughly intermediate between drinking water samples and the 11-23 October integrated rainwater end-member source. Such influence is also revealed by the change in sewage hydrochemistry at downstream sampling sites. Figure 9 indicates that while sodium and chloride concentrations have been halved between JB and PV sampling sites, the sewage has acquired calcium and barium, the solute concentrations of those increasing by a factor of 2 . Indeed, PV is positioned approximately halfway between rainwater and JB in the $\delta \mathrm{D}-\delta^{18} \mathrm{O}_{\mathrm{H} 2 \mathrm{O}}$ space.

However, the increase in calcium concentration can not be related to a release of stormwater from a detention basin. Instead, as rainwater infiltrates through the vadose zone, 
the weak acid formed from the solubilization of $\mathrm{CO}_{2}$ gas promotes the dissolution of minerals and the release of $\mathrm{Ca}^{2+}$ ions when the ground is dominated by carbonates (Stumm and Morgan 1996). The change in the isotopic composition of sewage is then consistent with a significant rainwater percolation in the sewer system. Groundwater infiltration may however dominate at RA and LO sampling sites, the isotopic characteristics of these sewage samples being located close to the groundwater line (GWL).

The isotopic compositions of sulphur and oxygen in dissolved sulfate are presented in figure 8b. Drinking water shows a slight depletion in both ${ }^{34} \mathrm{~S}$ and ${ }^{18} \mathrm{O}$ between $24-25 \mathrm{Oct}$. and 27-28 Oct. that can be interpreted as an intensification of the coagulation process applied to clarify Moselle river water. The isotope data from dissolved sulfate in groundwater appear to plot along a mixing line, thus suggesting the presence two main local aquifers of differing water quality in the urban watershed. Most isotopic values of dissolved sulfate in sewage are clustered between drinking water and urine pools. Unlike water isotopes, rainwater percolation in the sewer system can not be easily detected from the sulfate isotopic signature of sewage since the sulfate concentration in precipitations is quite low (Brenot et al. 2007). Two sewage samples show a drastically different behavior: (i) CL sewage, taken from a domestic sewer, is characterized by a dissolved sulfate enriched in ${ }^{34} \mathrm{~S}$, which might be attributed to bacterially mediated $\mathrm{SO}_{4}$ reduction with removal of lighter $\mathrm{H}_{2} \mathrm{~S}$ species; (ii) the relatively low $\delta^{34} \mathrm{~S}_{-} \mathrm{SO}_{4}$ value of RA sewage supports a significant groundwater infiltration at this sampling site.

\section{CONCLUSION}

This study confirms the interest of a multi-component approach to unravel the complex nature of hydrologic phenomena that may occur in an urban sewer. Thus, typical processes such as (i) groundwater infiltration, (ii) stormwater release from a retention basin, and (iii) rainwater percolation, were readily identified from the combined use of isotopic and hydrochemistry data. Water stable isotopes were effective tools for determining the quantity and the nature of clear waters entering the sewer system. Isotopes from dissolved sulfate were also found appropriate for constraining the origin of water inputs, but could not be used to evaluate the contributions of infiltrating water to the sewage flow due to the non-conservative behavior of dissolved sulfate. Diurnal sampling campaigns at a given sampling site always provided valuable information about the local functioning of the sewer system, provided that all end-member sources could be identified. In contrast, spatial sampling of sewage conducted 
at the urban catchment scale, showed various entries of clear waters and thus introduced supplementary difficulties in the interpretation of results.

Acknowledgements : This study was mainly supported by a grant from CNRS-INSU (ECODYN). Lorraine Region also provided part of the funding through Zone Atelier Moselle. We are grateful to M. Piqué and M. Villeroy (Service hydraulique CUGN) for logistical support during all field studies. We thank S. Bouly (ASGA) for providing hydrogeological information on CUGN piezometers. G. Frappier, J. Sieliechi, A. de Carvalho, and E. Montargès-Pelletier conducted sampling in the field, and this project would not have been possible without their precious help. We also wish to thank the staff of SARM (CRPG-UPR 80) where ICP analyses were carried out.

\section{REFERENCES}

Barrett, M.K., Hiscock, K.M., Pedley, S., Lerner, D.N., Tellam, J.H., French, M.J., 1999. Marker species for identifying urban groundwater recharge sources: a review and case study in Nottingham, UK. Water Res. 33 (14), 3083-3097.

Berner, Z.A., Stüben, D., Leosson, M.A., Klinge, H., 2002. S- and O-isotopic character of dissolved sulphate in the cover rock aquifers of Zechstein salt dome. Appl. Geochem. 17, 1515-1528.

Brenot, A., Carignan, J., France-Lanord, C., Benoît, M., 2007. Geological and land use control on $\delta^{34} \mathrm{~S}$ and $\delta^{18} \mathrm{O}$ of river dissolved sulphate: the Moselle river basin, France. Chem. Geol. 244, 25-41.

Butler, M.J., Verhagen, B.T., 1997. Enverimental isotopic tracing of water in the urban environment of Pretoria, South Africa. In Problems, Processes and Management, eds. P. J. Chilton, et al., Groundwater in the Urban Environment, Vol 1. Balkema, pp. 101-106.

Calmels, D., Gaillardet, J., Brenot, A., France-Lanord, C. 2007. Sustained sulfide oxidation by physical erosion processes in the Mackenzie river basin: climatic perspectives. Geology, 35(11), 1003-1006.

Chambers, L.A., Trudinger, P.A. 1979. Microbial fractionation of stable sulfur isotopes: a review and critique. Geomicrobiology Journal 1, 64-71.

Chocat, B. 1997. Encyclopédie de l'hydrologie urbaine et de l'assainissement. Lavoisier, Technique et Documentation.

Craig H., Gordon L.I. 1965. Deuterium and oxygen 18 variations in the ocean and the marine atmosphere. In: Togiorgi E. (Ed.), Stable isotope in oceanographic studies and paleotemperatures. Laboratorio di Geologia Nucleare, Pisa, Italy, pp 9-130. 
Epstein, S., Mayeda, T., 1953. Variation of $\delta^{18} \mathrm{O}$ content of waters from natural sources. Geochim. Cosmochim. Ac. 4, 213-224.

Fitzgerald, J.W. 1976. Sulfate ester formation and hydrolysis: a potentially important yet often ignored aspect of the sulfur cycle of aerobic soils. Bacteriological Rev. 40(3) 698721.

Gibson, J.J., Birks, S.J., Edwards, T.W.D. (2008) Global prediction of $\delta_{\mathrm{a}}$ and $\delta^{18} \mathrm{O}-$ $\delta^{2} \mathrm{H}$ evaporation slopes for lakes and soil water accounting for seasonality. Global Biogeochemical Cycles 22, GB2031.

Giesemann, A., Jäger, H-J., Norman, A.L., Krouse, H.R., Brand, W.A. 1994 On-line sulfur isotope determination using an elemental analyzer coupled to a mass spectrometer. Analytical Chemistry 66, 2816-2819.

Goldhaber, M.B., Kaplan, I.R. 1980. Mechanisms of sulfur incorporation and isotopic fractionation during early diagenesis in sediments of the Gulf of California. Mar. Chem. 9, 95-143.

Hvitved-Jacobsen, T., Raunkjaer, K., Nielsen, P.H. (1995) Volatile fatty acids and sulfide in pressure mains. Wat. Sci. Tech. 31(7), 169-179.

Hoffer, L.J., Hamadeh, M.J., Robitaille, L., Norwich, K.H. 2005. Human sulfate kinetics. Am. J. Physiol. Regul. Integr. Comp. Physiol. 289, R1372-R1380.

Houhou, J., Lartiges, B.S., Hofmann, A., Frappier, G., Ghanbaja, J., Temgoua, A. 2009. Phosphate dynamics in an urban sewer: a case study of Nancy, France. Wat. Res. (in press).

Knöller, K., Vogt, C., Feisthauer, S., Weise, S., Weiss, H., Richnow, H.H., 2008. Sulfur cycling and biodegradation in contaminated aquifers: insights from stable isotope investigations. Environ. Sci. \& Technol. 42(21), 7807-7812.

Koziet, J.S. 1997. Isotope ratio mass spectrometric method for on-line determination of oxygen 18 in organic matter. Journal of Mass Spectrometry 32, 103-108.

Kracht, O., Gujer, W., 2005. Quantification of infiltration into sewers based on time series of pollutant loads. Water Sci. Technol. 52 (3), 209-218.

Kracht, O., Gresch, M., Gujer, W., 2007. A stable isotope approach for the quantification of sewer infiltration. Environ. Sci. Technol. 41 (16), 5839-5845.

Krouse, H.R., Grinenko, V.A. 1991. Stable Isotopes. Natural and anthropogenic sulfur in the environment. SCOPE, 43, Wiley Chichester, U.K., 267-306.

Legret, M., Pagotto, C. 1999. Evaluation of pollutant loadings in the runoff waters from a major rural highway. The Science of the Total Environment 235, 143-150.

Lundquist, P., Martensson, J., Sörbo, B., Ohman, S. 1980. Turbidimetry of inorganic sulfate, ester sulfate, and total sulfur in urine. Clin. Chem. 26(8), 1178-1181. 
Marsalek, J., Jiménez-Cisneros, B.E., Malmquist P-A., Karamouz, M., Goldenfum, J., Chocat, B. 2006, Urban water cycle processes and interactions. IHP-VI Technical Documents in Hydrology. No. 78, UNESCO, Paris.

Mook, W.G. 2001. Environmental isotopes in the hydrological cycle. Principles and applications. IHP-V. Technical documents in hydrology. No. 39. UNESCO-IAEA.li

Morrison, J., Brockwell, T., Merren, T., Fourel, F., Phillips, A.M., 2001. On-line highprecision stable hydrogen isotopic analyses on nanoliter water samples. Anal. Chem. 73 (15), 3570-3575.

Navarro, A., Carbonell, M., 2007. Evaluation of groundwater contamination beneath an urban environment: the Besòs river basin (Barcelona, Spain). J. Environ. Manag. 85, 259269.

Osenbrück, K., Gläser, H., Knöller, K., Weise, S.M., Möder, M., Wennrich, R., Schirmer, M., Reinstorf, F., Busch, W., Strauch, G., 2007. Sources and transport of selected organic micropollutants in urban groundwater underlying the city of Halle (Saale), Germany. Water Res. 41, 3259-3270.

Rudnicki, M.D., Elderfield, H., Spiro, B. 2001. Fractionation of sulfur isotopes during bacterial sulfate reduction in deep ocean sediments at elevated temperatures. Geoch. Cosmochim. Acta 65, 777-789.

Stumm, W., Morgan, J.J. 1996. Aquatic chemistry. Whiley Intersciences.

Udert, K.M., Larsen, T.A., Gujer, W. 2003. Estimating the precipitation potential in urine-collecting systems. Wat. Res. 37, 2667-2677.

Valiron, F. and Tabuchi, J.P. 1992. Maîtrise de la pollution urbaine par temps de pluie - Etat de l'art. Agence de l'Eau Seine-Normandie / AGHTM. Tech \& Doc, Lavoisier, 564p.

Van Everdingen, R.O., Krouse, H.R. 1985. Isotope composition of sulphates generated by bacterial and abiological oxidation. Nature, 315, 395-396.

Verbanck, M.A., 1993. A new method for the identification of infiltration waters in sanitary flows. Water Sci. Technol. 27 (12), 227-230.

Vollertsen, J., Nielsen, A.H., Jensen, H.S., Hvitved-Jacobsen, T. (2008) Modeling the formation and fate of odorous substances in collection systems. Wat. Environment Res. 80(2), 118-126.

Yu, J-Y., Park, Y., Mielke, R.E., Coleman, M.L. 2007 Sulfur and oxygen isotopic compositions of the dissolved sulphate in the meteoric water in Chuncheon, Korea. Geosciences Journal 11(4), 357-367.

Zhang, L., De Schryver, P., De Gusseme, B., De Muynck, W., Boon, N., Verstraete, W., 2008 Chemical and biological technologies for hydrogen sulfide emission control in sewer systems: A review. Wat. Res. 42, 1-12. 